\title{
Assessment of Integrated Solid Waste Management Practices in Adama City, Oromia Region, Ethiopia
}

\author{
Kitila Alemayehu Mijena ${ }^{1,2}$, Jianfu Zhao ${ }^{2}$, Sha Lu ${ }^{3}$, Tao Wang ${ }^{1,4, ~ *}$, Kitila Gizachew Mijena ${ }^{5}$ \\ 1. Tongji University, UNEP-Tongji Institute of Environment for Sustainable Development (IESD)Shanghai 200092, P.R. China. \\ 2. College of Environmental Science and Engineering, Tongji University, Shanghai \\ 3. Circular Economy Research Institute, Marxism Faculty, Tongji University, Shanghai \\ 4 Institute for Advanced Study, Tongji University, Shanghai \\ 5. Government of Ethiopia and Oromia Regional State, Bureau of Labor and Social Affairs, Employment Study Expert \\ * Corresponding author \\ DOI: 10.29322/IJSRP.11.02.2021.p11054 \\ http://dx.doi.org/10.29322/IJSRP.11.02.2021.p11054
}

\begin{abstract}
Waste management is an environmental challenge for many countries around the world. Management of municipal solid waste is especially critical for cities in the developing world, mainly because of insufficient municipal institutional capability, low bureaucratic competence, and poorly developed infrastructure. Fast urbanization in the developing world has led to increasing generation beyond the capacity that the cities can collect, transport, dispose, and handle the adverse impacts. In this study, an assessment of integrated solid waste management (ISWM) practice was conducted in Adama City, Oromia, Ethiopia, one of the rapidly urbanizing cities in the country. However, the city has been threatened by difficulties in delivering proper solid waste management (SWM) service effectively and efficiently. Hence, this study aimed to assess the SWM practice of Adama City and to investigate integrated management strategies for the city. The study used an explanatory research method. Primary data were collected through interviews supplemented by field observation and selfadministered questionnaires, whereas, secondary data were gathered from different quantitative and qualitative documents. Data from primary and secondary sources were used and analyzed with statistical tools. The findings of the study reveal that, though there were great efforts made for ISWM practice in the city, improper SWM practices existed in the city and serious environmental and health consequences were caused due to weak institutional capacity and governance. The study showed that the average waste generation per capita in the Adama City was $0.42 \mathrm{~kg} /$ day/person in 2020 , beyond the national average level of $0.33 \mathrm{~kg} /$ day $/$ person. In total, about 69,536 metric tons of waste were generated in the city annually. Therefore, a sustainable transition of the current SWM practices are surely needed to overcome the environmental, economic, and social challenges caused by ineffective and inefficient waste management in the city.
\end{abstract}

Keywords- Adama City, Integrated Solid Waste Management, Waste Generation, Waste Storage, Waste Transportation.

\section{INTRODUCTION}

\section{Background of the Study}

Waste is a major and growing challenge for humans. By 2050, scientific studies show that waste generation is expected will be increased by $70 \%$ globally [1]. The waste management in a given country is directly influenced by economic, social, and political drivers of that country[2]. Integrated solid Waste Management (ISWM) is a holistic framework focused on recycling, composting and disposal programs for a waste management system. It includes the assessment of environmental conditions and needs, and then the selection and combination of the most suitable activities for waste management under those conditions. ISWM is becoming increasingly important for urban management in developing countries [3]. This is mainly due to the rapid expansion of cities and rapid population growth, which accelerates the municipal solid waste generation rate [4]. According to (Daniel Hoornweg and Perinaz Bhada-Tata 2012) [5], developing countries spend about $\$ 46$ billion per year on municipal solid waste. The investment may exceed $\$ 150$ billion by 2025 . Nonetheless, ISWM in Africa including Ethiopia is often weak due to lack of appropriate planning, inadequate governance, limited technology, weak enforcement of existing legislation, and insufficient economic incentives [6].

In most African countries, solid waste arising from domestic, social, and industrial activities is increasing in quantity and variety as a result of the growing population [7]. The waste generation and discharge can cause harmful impact onto animals, plants, ecosystems, and the environment. This 
waste management is in need to limit the damage to the environment and to recover scarce resources[8]. ISWM services in Ethiopia were mainly a duty to municipalities. The service provision is threatened by lack of collection and sanitary facilities and improper planning and coordination [9]. Until recently, waste was given a low priority in most municipalities and government agencies [10]. Today, solid waste is removed and either sent to disposal or is reprocessed for subsequent use. To make waste management sustainable and environmentally friendly, an integrated approach is needed to coordinate the social, cultural, economic, and ecological impacts [11].

This ISWM approach should be first compatible with the nature of a given society [12]. Many studies on ISWM in developing countries have revealed that waste quantities and composition vary according to the characteristics of a place, and the management must be adapted to certain limitations common to these settings [13]. Some of these difficulties are attributed to the deficiency of management regulations in developing countries, including Ethiopia and Adama City. On the one hand, new regulations are not always consistent to waste management practice, due to lack of transparency in the participants' duties and exposures. This approach is concerned with a radical change of attitude and habits towards solid waste collection and disposal. Every aspect of environmental cleanliness and protection serves as a drive to holistic waste management. Thus, treating waste as a recyclable resource will be pivotal to bringing sustainability. In the city of Adama, there is an inadequate waste collection system, leading to the disposal of solid waste in drainage systems and open spaces. This exacerbates flooding and raised public health risks. The city has developed dump sites outside the city, but neither operating capacity nor appropriate equipment and vehicles are sufficiently available [14]. Overall, coordination of waste management and other services (e.g., construction, public health) is critical to improve urban resilience [15]. The public awareness of the waste damages is also to be enhanced [16].

To address the above challenges, it is surly necessary to assess the solid waste management practice of Adama city and to investigate integrated management strategies. The gaps in the current system will have to be addressed by promoting waste recycling and identify technologies for the treatment and disposal of residual waste [17]. To develop a supporting framework, there is a need to identify appropriate policy interventions, including economic implementation, and monitoring. The study also aims at generating vital information for developing and implementing an ISWM plan so that the waste constituents can be recycled and reused to a maximum possibility, and the development of the city can take place in harmony with the environment. The study starts with waste source identification and characterization of different types of wastes from households. Major waste transport routes and disposal sites has been identified, and factors that influence the waste management practice of Adama city towards ISWM have been examined in all six sub-cities in Adama, i.e., Abba Gada, Bole, Dambala, Dabe, Boku, and Lugo.

\section{RESEARCH DESIGN AND METHODOLOGY Descriptions of the Study Area}

This research was conducted in the city of Adama, located in the National Regional State of Oromia in Ethiopia. With 18 Kebele and Six Sub City administrations, Adama is the capital of the Eastern Shewa zone. The city of Adama is situated at $8.54^{\circ} \mathrm{N}$ and $39.27^{\circ} \mathrm{E}$, at an altitude of $1712 \mathrm{~m}$, around 99 $\mathrm{km}$ southeast of Addis Ababa. The city has a total area of 31,287.83 hectares (OUPI, surveying 2017) [18]. It is a rapidly growing major city in central Ethiopia near Addis Ababa, with an overall population of 500,000 in 2018[19]. In the north, east, and west, it is surrounded by hills. The temperatures for the season are 16 to $32{ }^{\circ} \mathrm{C}$. The location of Adama City is shown in (Figure 1).

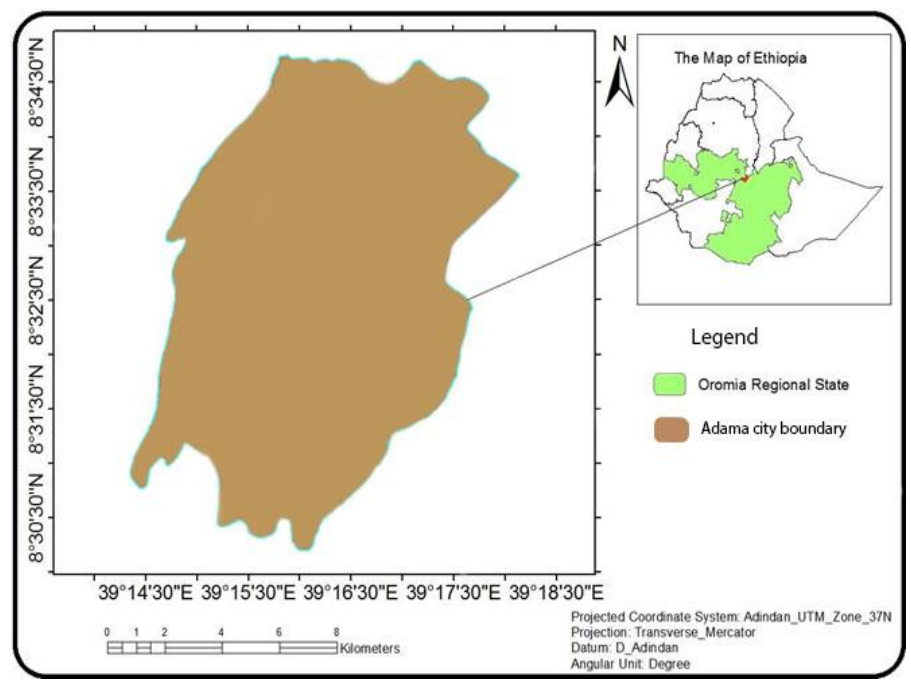

Figure 1: Geographical Location of the Study Area. Source: Oromia Urban Planning Institute

\section{Data Sources and Collection}

The research method employed in the study is the explanatory research method. which is helpful to identify the causal relationships primary and secondary sources of data are collected. For the primary data collection, rapid appraisal, questionnaires survey, stakeholders' interviews, and field observations are conducted at the household and individual levels. Secondary data collection includes published literature, official reports and legal documents. By doing so, qualitative and quantitative information was obtained. Adama city administration has six sub-cities namely, Aba Geda, Roku, Dabe, Bole, Lugo, and Dambela. There is 18 kebele under the administration of these sub-cities. To ensure the reliability of the research data, the study covers all the sub-cities and kebele administrations in which respondent households were randomly selected.

\section{Sample Size Determination}

To determine the sample size, a formula provided by Taro Yamane was utilized [20-23]. Assuming the city population size was around 500,000 and the number of 
households was estimated to be 95,823 based on the projection of Ethiopian Statistical Agency, 2007. With a confidence level of $95 \%$ and a Margin of error (0.05), the sample size of 402 was obtained based on the calculation. The formula used was described as follows [20].

Where

$$
\mathrm{n}=\mathrm{N} /\left(1+\mathrm{N}\left(\mathrm{e}^{2}\right)\right)
$$

$$
\begin{aligned}
& \mathrm{N} \text { - is the total population } \\
& \mathrm{n}-\text { is the required sample size } \\
& \mathrm{e}-\text { is the margin error }
\end{aligned}
$$

\section{Sampling Techniques}

Among 95,823 households in the study area, 402 households were selected from 18 kebeles proportionately and respondents were selected randomly from each stratum. At the same time, most influential persons (e.g. leaders) from the residents were contacted on purpose to obtain more accurate information. While 2 officials from the sanitation administration team of Adama City municipality and 3 from the Sanitation Cooperative Partnership Association leaders were selected on purpose because it is more appropriate to obtain information from whom it may concern.

\section{RESULTS AND DISCUSSION}

\section{Demographic Characteristics of the Sample Household Survey}

Studies have shown that characteristics of households who produce wastes vary quantitatively and qualitatively, including income, food habits, family size and lifestyle, and educational and occupational status. The characteristics of the respondents in this study are described in the table below (Table

\begin{tabular}{|c|c|c|c|}
\hline $\begin{array}{c}\text { Respondents } \\
\text { Characteristics }\end{array}$ & $\begin{array}{l}\text { Demographic } \\
\text { Classification }\end{array}$ & $\begin{array}{c}\text { Number of } \\
\text { Respondents }\end{array}$ & $\begin{array}{c}\text { Percentage } \\
(\%)\end{array}$ \\
\hline \multirow{3}{*}{$\begin{array}{l}\text { Total number } \\
\text { and Sex of } \\
\text { Respondents }\end{array}$} & $\mathrm{M}$ & 193 & 48.01 \\
\hline & $\mathrm{F}$ & 209 & 51.99 \\
\hline & Total & 402 & 100 \\
\hline \multirow{5}{*}{$\begin{array}{l}\text { Age Group of } \\
\text { Respondents }\end{array}$} & $15-24$ & 66 & 16.42 \\
\hline & $25-34$ & 203 & 50.50 \\
\hline & $35-64$ & 132 & 32.84 \\
\hline & 65 and above & 1 & 0.25 \\
\hline & Total & 402 & 100 \\
\hline \multirow{5}{*}{$\begin{array}{l}\text { Education } \\
\text { Level of the } \\
\text { respondents }\end{array}$} & $\begin{array}{l}\text { No Formal } \\
\text { Education }\end{array}$ & 2 & 0.5 \\
\hline & $\begin{array}{ll}\text { Grade } & 1-4 \\
\text { Complete } & \\
\end{array}$ & - & - \\
\hline & $\begin{array}{ll}\text { Grade } & 5-8 \\
\text { Complete } & \\
\end{array}$ & 12 & 2.99 \\
\hline & $\begin{array}{ll}\text { Grade } & 9-12 \\
\text { Complete } & \\
\end{array}$ & 93 & 23.13 \\
\hline & $\begin{array}{l}\text { Certificate, } \\
\text { Diploma, and } \\
\text { above }\end{array}$ & 295 & 73.38 \\
\hline
\end{tabular}
$1)$.

Table 1: Demographic Characteristics of Sample Household Survey

\begin{tabular}{|c|c|c|c|}
\hline & Total & 402 & 100 \\
\hline \multirow{11}{*}{$\begin{array}{l}\text { Family Size of } \\
\text { the } \\
\text { Respondents }\end{array}$} & 1 & 47 & 11.69 \\
\hline & 2 & 79 & 19.7 \\
\hline & 3 & 74 & 18.4 \\
\hline & 4 & 70 & 17 \\
\hline & 5 & 61 & 15 \\
\hline & 6 & 34 & 8.5 \\
\hline & 7 & 19 & 4.7 \\
\hline & 8 & 11 & 2.7 \\
\hline & 9 & 2 & 0.5 \\
\hline & 10 & 5 & 1.2 \\
\hline & Total & 402 & 100 \\
\hline \multirow{6}{*}{$\begin{array}{l}\text { Average } \\
\text { Monthly } \\
\text { Income Level } \\
\text { of the } \\
\text { Respondents } \\
\text { (in Eth. Birr) }\end{array}$} & Less than 1000 & 55 & 13.68 \\
\hline & $1001-2000$ & 37 & 9.2 \\
\hline & $2001-2005$ & 28 & 6.97 \\
\hline & $2501-3000$ & 43 & 10.7 \\
\hline & Above 3000 & 239 & 59.45 \\
\hline & Total & 402 & 100 \\
\hline \multirow{4}{*}{$\begin{array}{l}\text { House } \\
\text { Ownership } \\
\text { Condition of } \\
\text { the } \\
\text { respondents }\end{array}$} & Private & 118 & 29.35 \\
\hline & Gov't Rental & 38 & 9.45 \\
\hline & Private Rental & 246 & 61.19 \\
\hline & Total & 402 & 100 \\
\hline
\end{tabular}

This publication is licensed under Creative Commons Attribution CC BY. http://dx.doi.org/10.29322/IJSRP.11.02.2021.p11054
Table 1 showed that $48 \%$ of the respondents were males and $52 \%$ of them were females. In terms of the respondents' age group, about $50.50 \%$ of them were within the range of 25-34 years old, $32.84 \%$ of them were within the range of 35-64 years old. In general, respondents are matured enough for giving such type of data. The respondents had different educational backgrounds as well. For instance, $73.38 \%$ of them were graduated from higher educational institutions with a certificate, diploma and above, $23.13 \%$ of them were completed grade $9-12$, about $2.99 \%$ of them have completed their primary education, and only $0.5 \%$ of them did not have any formal educational background. Accordingly, the majority of the respondents had a certificate and above level of formal educational background. Hence, respondents are considered to be capable of thinking, analyzing and responding in a responsible and trustworthy way.

Out of the 402 respondents, about 79 households had 2 family members, 70 households had 4 family members, and 61 households had 5 family members. In general, more than $50 \%$ of the respondents had four and more family members. It is shown that the average household size of the household respondents is 3.74. When it comes to the income, most of them $(59.45 \%)$ have more than 3000 Birr per month. However, some respondents gain less than 1000 ETB which is less than 1USD per day. Of the total respondents, $61.19 \%$ of them live in a private rental house and $29.35 \%$ of them live in their own house. The rest $9.45 \%$ of the respondents live in governmentowned rental houses.

\section{Institutional Frameworks}


The Federal Democratic Republic of Ethiopia comprises ten federal states. The federal government is responsible for integrating the state regions, allocating budgets to states, and enforcing laws. The functions and responsibilities of the regional state's guide their region by planning, directing, and administering social and economic programs, and by integrating the natural resources to the development and growth laws as a whole. The basic administrative units in each regional government are the warheads, sub-units of which are the kebeles. Further, based on their authority and responsibilities the regional governments have established sectoral bureau and authorities. Accordingly, there are three main city-level offices involved in urban solid waste management practices, namely, Environmental Protection and Climate Change Authority, Health Protection Office, and the Municipality. The first two sectors are primarily involved in enforcing regulations on sanitation and waste management. The municipality is involved in the provision of services needed for solid and liquid waste collection and disposal.

The city administration is structured at three different levels: city, sub-city and kebele. At the city level out of the 5 required manpower all employees are available. However, at the sub-city level, out of 6 sub-cities only in 2 sub-cities sanitation and green development team leaders are available. At kebele level, out of 18 kebeles only in 9 kebeles sanitation and green development team leaders are available. This shows that the human resource required for solid waste management at sub-city and kebele level is very limited. But, organizing of micro and small enterprises engaged in urban sanitation could be done at these government levels and could be sent to sanitation coordination team/expert for operation and close supervision and monitoring of the same. Hence, close supervision of MSEs involved in solid waste collection activity by the concerned sub city and/or kebele sanitation experts is not effective. Besides this, as the information obtained from the team leader of sanitation of the municipality, at the sub-city and kebele level turnover of employees of sanitation department are high in seek of joining job titles of their profession. This also shows that employees are working without the knowledge and profession of urban sanitation management. Adama Science and Technology University is one of the stakeholders mostly role out by conducting research and study works in the sector. There are also different NGOs participate in supporting funds, providing expertise in the design of landfill structure and developing waste management plans, awareness-raising, developing compost preparation workshops, and households and commercials participate in primary collection and paying the service fee. Industries receive recyclable wastes from sellers to use as input for their production. The institutional structure for solid waste management system employed in the city could be summarized as shown in (Figure 2) below.

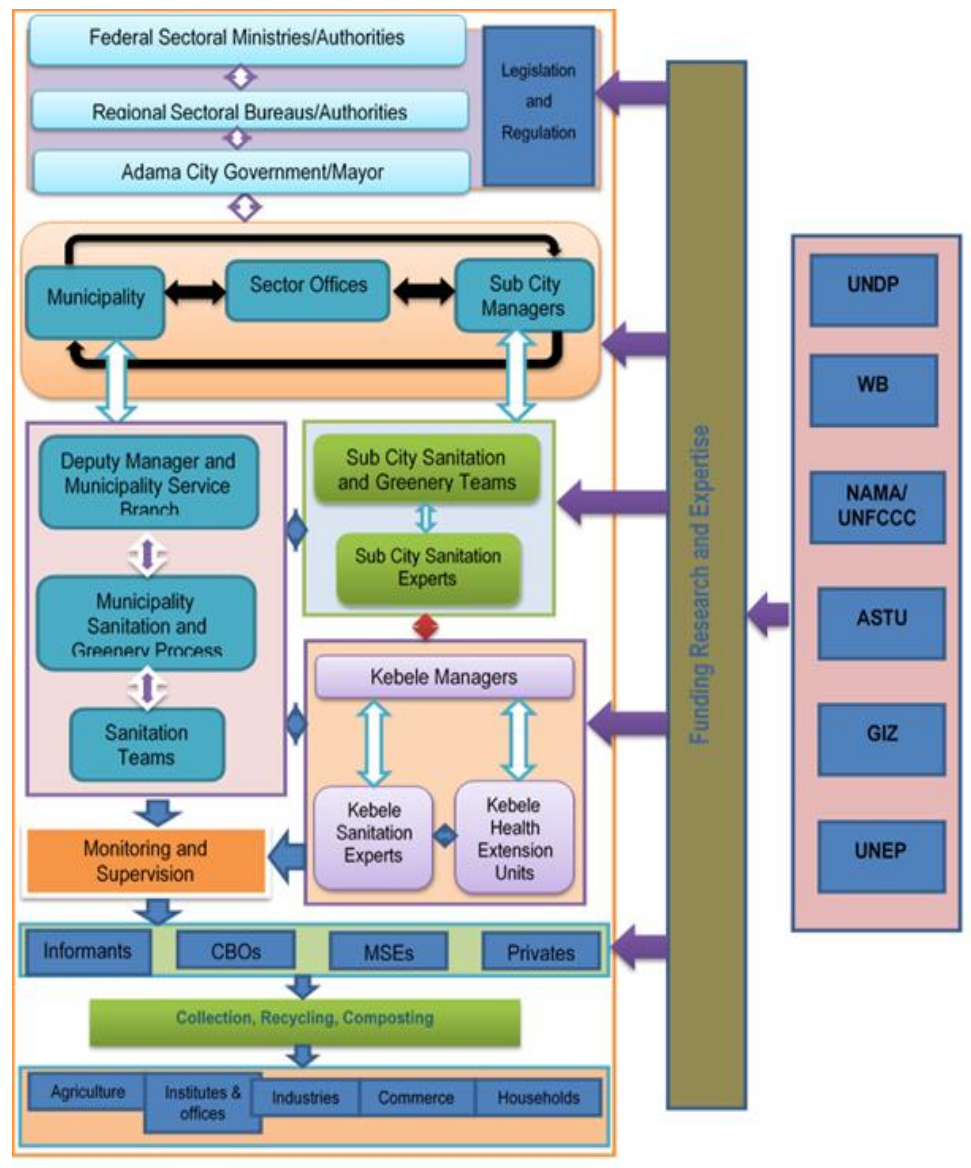

Figure 2. Institutional Structure for Solid Waste management system.

Source: Survey result, 2020

\section{The Trends of Solid Waste Management in Adama City}

Municipal Solid Waste Management (MSWM) is the generation, separation, collection, transfer, transport, and disposal of waste in a way that is responsive to public needs and takes into account environmental protection, sustainability, recycling, aesthetics, and the community. According to the World Bank [24], The ultimate objective of solid waste management is to collect, treat, and dispose of solid waste in an environmentally and socially acceptable manner. Solid waste management in Adama city begun in the early 1960s. A wheelbarrow, locally called "kurikur", was used to transport the wastes to the Dejazmach Amdie neighborhood on the way to today's abattoir, which was the edge of the city by then. The work was done by the municipality in general and had no specific body to handle it[25].

As practiced in many of the cities in Ethiopia, the Municipality of Adama has partly outsourced the waste management practice in the city to formally organized associations/partnerships to collect wastes from households, ditches and streets and transport them to the transfer station. The pre-collected waste is then transferred into containers 
which are then collected by the municipality. Nevertheless, in the city, there are not enough containers and vehicles are very limited which are typically under maintenance or out of service for long periods. There are also organized associations that are engaged in the collection and segregation of recyclable wastes and sell it to producers for reuse. Waste management practice in the city, as it was very limited to recycling, reuse, or recover.

\section{Solid Waste Generation and Management Practices}

As specifically specified in Solid Waste Management Proclamation No. 513/2007, "Solid Waste" refers to something that is not liquid or gas and is discarded as unwanted, while "Solid Waste Management" means the collection, storage, transportation, recycling, or disposal of solid waste, or the resulting use of an operational disposal site. Adama is known as the center of the conference, tourism, and industries in the country. Therefore, there are large amount of economic activities conducted and, serve a large amount of population that generates a large volume of wastes. Currently, all activities in the waste management chain, are conducted on the daily basis, include waste collection, waste transfer, transportation, recycling, composting, and disposal of wastes. Households clean their house at different day intervals but the majority clean their house every day. Accordingly, 332 (82.59\%) of the respondents do it every day. However, very few (1.24\%) of them clean their house within more than a week. Consequently, there is a large amount of waste production every day at each household level, which contributes to the city's environmental and health problems.

The amount of waste generation varies depending on the income level. The average rate of waste generation in most industrialized countries lie between 0.8 and $1.4 \mathrm{~kg}$ per capita per day, while in developing countries, the average waste generation capacity of a single person is $0.33 \mathrm{~kg} /$ day $/$ person[26]. In terms of the total waste generation in urban areas of Ethiopia, only $29.2 \%$ could be collected and the rest $70 \%$ would be left on roadsides, in ditches, on the riverside, green areas, and other open spaces[27], shows that the average amount of solid waste per capita generation in Adama city is $0.15 \mathrm{~kg} / \mathrm{cap} / \mathrm{day}$. The annual solid waste generation from the streets account $3750 \mathrm{~m}^{3}$ and $2340 \mathrm{~m}^{3}$ could be collected by the street sweepers in Adama city. This comprises $63 \%$ of the streets waste generation. Hence, a large proportion of the solid waste is left uncollected or disposed of in open spaces, in ditches, and rivers. This is mainly due to insufficient waste collection and the lack of public awareness. Adama city is a residential, commercial, conference, and industrial center of the country, the amount of waste generation is estimated to be more than 71700 metric tons each year[28].

The study conducted by the municipality of Adama city administration in 2020 shows that the daily per capita solid waste generation rate for the low, middle, and high-income group is found to be $0.29 \mathrm{~kg}, 0.4 \mathrm{~kg}$, and $0.57 \mathrm{~kg}$ respectively. The households waste generation rate for low income, middle income, and high-income household is found to be $1.45 \mathrm{~kg}, 2 \mathrm{~kg}$, $2.85 \mathrm{~kg}$ respectively (Table 2 ).

Table 2: Solid Waste Generation Rate in Adama City.

\begin{tabular}{|l|c|c|c|}
\hline & $\begin{array}{c}\text { Low } \\
\text { Income } \\
\text { Housing }\end{array}$ & $\begin{array}{c}\text { Middle } \\
\text { Income } \\
\text { Housing }\end{array}$ & $\begin{array}{c}\text { High } \\
\text { Income } \\
\text { Housing }\end{array}$ \\
\hline $\begin{array}{l}\text { Average } \\
(\mathrm{Kg} / \mathrm{HH} / \mathrm{D})\end{array}$ & 1.45 & 2 & 2.85 \\
\hline $\begin{array}{l}\text { Average } \\
(\mathrm{Kg} / \mathrm{Cap} / \mathrm{D})\end{array}$ & 0.29 & 0.4 & 0.57 \\
\hline
\end{tabular}

Source: Adama Municipality, 2020.

Table 2 shows that the average waste generation per capita per day is $0.42 \mathrm{~kg}$ while the average waste generation rate of households is $2.1 \mathrm{~kg}$ per day. This in turn contributes to more than $210,000 \mathrm{~kg}$ or 210 tons per day waste generation in the city.

As practiced in many of the cities in Ethiopia, the municipality of Adama has partly outsourced the waste management practice to formally organized associations/partnerships to collect wastes from households and transport them to the transfer station/secondary collection site, clean ditches and streets, and prepare compost and recycle wastes. Accordingly, there are currently 164 micro and small enterprises that comprise more than 1500 members engaged in different waste management activities. Those enterprises engaged in the waste collection from households, commercial centers, and institutions collect wastes and transport them by hand carts or horse-driven carts to the transfer station/waste collection containers and load them on municipal waste disposal cars. The pre-collected waste is then transferred into containers which are then collected by the municipality to the compost preparation site for final segregation of decomposable wastes. Then, non-decomposable wastes are again taken by the municipality waste transport and disposal cars to the final disposal site.

Nevertheless, there are inadequate containers to serve all the residents in Adama The number of vehicles for wastes transport is very limited and some of them are even unavailable indefinitely due to maintenance or out of service. Compost preparation from biodegradable wastes has been taking place recently with very limited capacity by organizing interested youths in 2 micro and small enterprises. There are also organized associations engaged in the collection and segregation of recyclable wastes with which they can be benefited from providing raw materials to manufactures for the reuse. As the process of waste recycle, reuse, or recovery is relatively straightforward, waste disposal has been the major business mode in the area of waste management practice in Adama. Manufactures are responsible to handle their wastes properly and transport them to the final municipal disposal site by their means. However, the municipality charges them for polluting the environment as per the volume and nature of wastes at the disposal site. In general terms, the secondary waste collection activity is vested solely in the hands of the municipality. 


\section{Onsite Solid Waste Handling, Storage and Processing}

On-site handling refers to the activities associated with the handling of solid wastes until placed in the containers and used for storage before collection. Handling may also be required, depending on the type of collection service, to transfer the loaded containers to the collection point and return the empty containers to the point where they are stored between collections. Households' waste disposal behavior during solid waste management practices as the origin of wastes is a very crucial in order to manage wastes properly. If wastes are properly segregated and stored in accordance with their attributes, it is easier to handle wastes during the next step and potentially be used for further handling. In Adama, about $67 \%$ of the respondents of this study are less likely to store/segregate solid wastes properly. It is therefore difficult for wastes to be handled by recyclers, decomposers, and other interested individuals for environmental protection. Respondents who try to segregate wastes do this for different purposes. The major purpose to segregate and store wastes in the study city is described as follows in (Figure 3).

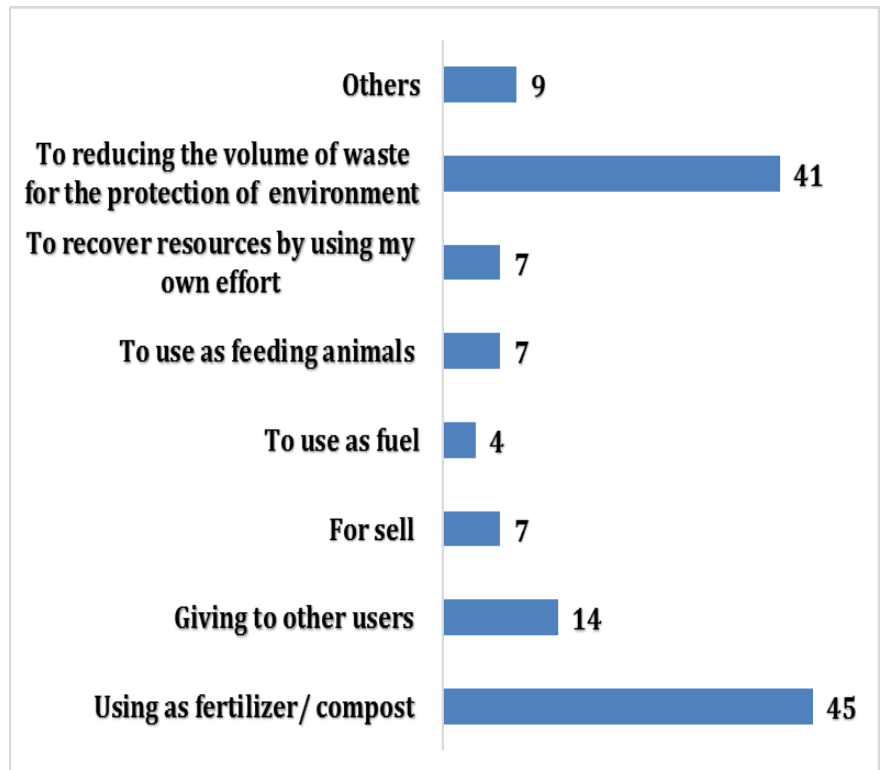

Figure 3: The purpose of the onsite segregation of wastes.

As shown in (Figure 3) above, the respondents who practiced segregation and store wastes for the purpose of using as fertilizer from decomposable wastes such as fruits and vegetable scraps, animal dung, etc. takes $34 \%$ share. The storage materials are described in the following (Figure 4) chart.

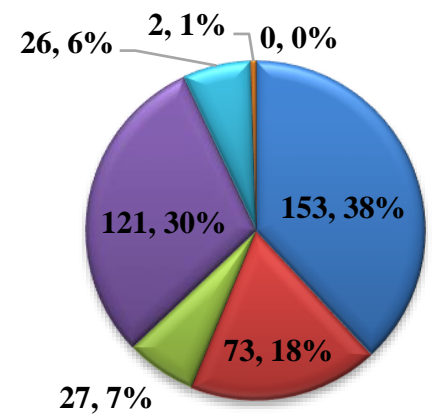

$\begin{array}{ll}\square \text { Sack } & \square \text { Bascket } \\ \square \text { Metal Container } & \square \text { Plastic Container/Bag } \\ \square \text { Private Pit } & \square \text { I don't use any thing } \\ \square \text { Others } & \end{array}$

Figure 4: Household's Waste Storage Materials.

People use different waste storage materials for their household wastes. As stated in the above chart, 38\% of the respondents use sacks for waste storage in their compound, whereas only30 \% of them use plastic bags. Availability of plastic bags are better and more convenient to carry in a proper manner. The municipality provides the community with temporary waste collection containers in their surroundings. For the effective management of solid wastes, scattering waste containers throughout the city is very important. There are 35 containers placed in different selected areas for the storage of wastes to be used as a waste transfer station in Adama city. When the containers are filled with wastes, regular follow-up by the concerned party is required for the in-time collection of containers for disposal of wastes and return them afterwards. In this regard, this service satisfies only $35 \%$ of the demand in the city. In case of vehicles shortage caused by malfunctions and maintenance, those containers fully filled with wastes could be postponed in collecting. In this case, wastes could be blown away to the neighborhoods by winds and carried by animals as shown in (Figure 5).

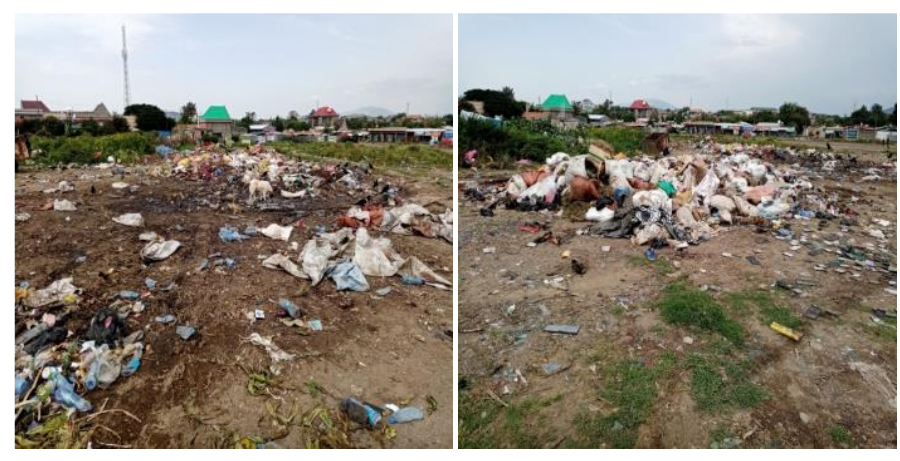

Figure 5: The current Conditions of Wastes at the site of transfer Stations. 
On the site of transfer stations, there is also a very limited effort of segregation of wastes especially recyclable wastes such as plastics and metals by waste scavengers. Then, the remaining wastes in these containers could be transported to the compost preparation site for the segregation of decomposable wastes and compost preparation. After decomposable wastes are segregated, non-decomposable wastes could be sorted out and then transported to the final waste disposal site.

\section{Solid Waste Disposal Practices and Management on Disposal Site}

There are three main approaches for wastes disposal and handling including sanitary landfills, and incinerators. However, the majority of domestic cities use open dumping sites, creating various negative impacts on the environment including human beings[26]. The final waste disposal site of Adama city is found in the southwest direction, $9.8 \mathrm{~km}$ away from the center of the city on the road to Finfinnee/Addis Ababa locally known as 'Jogo Goaded'. The site was selected as an alternative to the previous one in the 2004 master plan. The dumping site has been in service since 2002 and is officially administered under the Adama Municipality. Recently, in the revision of the structural plan of the city prepared by Oromia Urban Planning Institute for the coming 10 years stated that the previous site was again reserved for the final waste disposal site. However, the recommended distance for the selection of waste disposal site is not less than $2 \mathrm{~km}$ from a suitable main road and residential areas, but the current location is only 200 meters away from the main road and residential houses. It covers $14,000 \mathrm{~m}^{2}$ of land. on this site, the city is trying to develop it according to the ULGDP project budget, funded by the World Bank through the Ministry of Urban Development of the Federal Democratic Republic of Ethiopia. However, the neighboring community has rejected due to the concern of air pollution and potential in affecting domestic animals. Because of this complaint, the city administration has decided to change the waste disposal site to an extracted quarrying site against the structure plan of the city in response to the surrounding community's complaint.

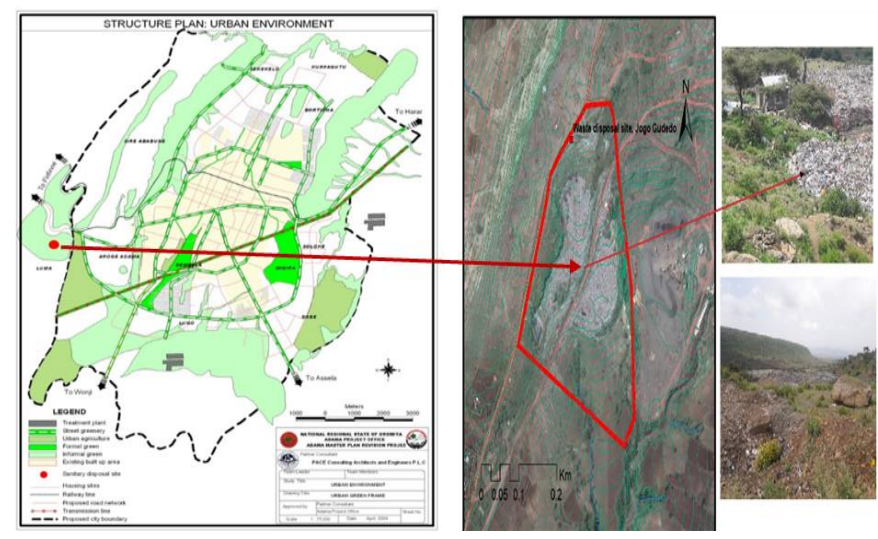

Figure 6: Previous Waste Disposal Site Proposed in the Structural Plan of the City
As shown in (Figure 6) above, the city used a controlled disposal system. The dumping site was not formally designed and developed as a landfill site. This was a simple site where garbage is being disposed of. All types of solid wastes generated in the city are dumped indiscriminately on the final disposal site, except from fencing and guarding. The solid and liquid final waste disposal site was found within the same compound. it is near the Aba Geda Conference Hall and between the Toll Road, connecting Adama and Finfinnee/Addis Ababa, and the ordinary main road connecting Finfinnee/Addis Ababa with Djibouti crossing Adama city in the gorge at the near distance of the previously poorly developed landfill site as shown in the following (Figure 7).

As shown in (Figure7), wastes on the disposal site are not properly managed. This site also has no proper fence which prevents animals from entering and it is creating a rotten smell whenever passengers crossing the roads on both sides. Following the gorge, it is dispersed to nearby farmlands and riverside by flooding and air. Each day more than 210 tons of solid wastes are expected to be disposed of by the municipality However, concerning the expected waste generation capacity per day $65 \%$ of solid waste in the city is properly disposed. Due to the lack of waste disposal capacity, $35 \%$ of solid waste is not disposed. As a result, the city's residents have become uncomfortable, resulting in environmental pollution. There are also other means of waste disposal methods other than door-todoor collection and disposal service practiced by the community.
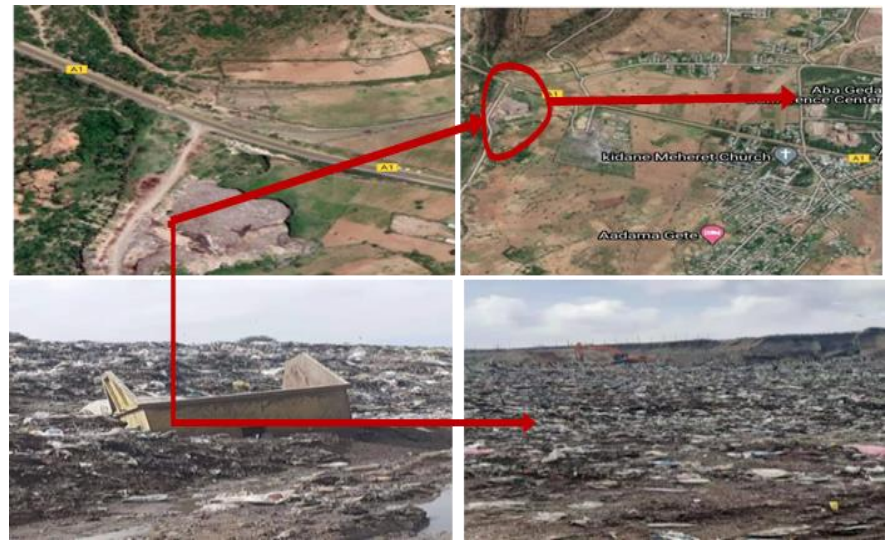

Figure 7: The Current Solid Waste Disposal Site against the Structure Plan of the City.

The use of informants for solid waste disposal is rarely practiced in the city. Burning in the compound, simply dispose of in the compound, burying inside the compound, damping in municipal containers around our dwelling, dumping under bridges dumping on the side of roads and open fields and others are also common in the city. For example, out of the 402 respondents in the study area, $138(34 \%)$ of them have practiced damping in municipal containers around their dwelling when both official and unofficial collectors did not empty containers in time. There are also irresponsible behaviors when disposing 
waste, which would result in environmental pollution could cause such as burning dumping and under bridges

\section{Composition of Solid Waste Generation}

With the information obtained from different participants, and direct observation to the study area, the sources and types of wastes generated in Adama City are described as follows in the (Figure 8).

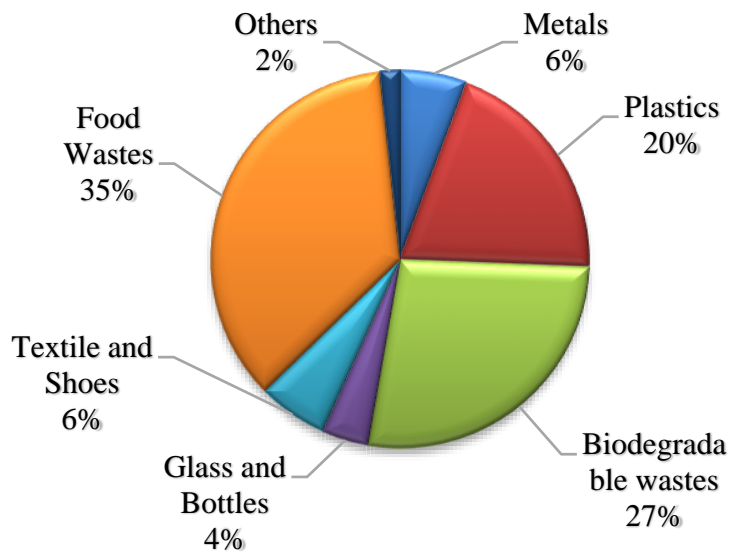
Metals
- Plastics
$\square$ Biodegradable wastes
$\square$ Glass and Bottles
$\square$ Textile and Shoes
$\square$ Food Wastes

Figure 8: The Major Compositions of Household Wastes of the Respondents.

Accordingly, the respondents of the study have shown that the major compositions of wastes produced from the respondents are food wastes, biodegradable wastes, and plastics respectively. Biodegradable wastes can be decomposed in the soil and fed on as food for domestic animals and input for the preparation of compost. Food wastes can also be used as food for domestic animals.

\section{Current Solid Waste Management Service}

Solid waste management is one of the services the town administration provides for its residents. As service quality, environmental impacts, and operational costs may vary dramatically, solid waste management is arguably the most important municipal service and serves as a prerequisite for other municipal action. In this regard, the study result shows that door to door collection service is one of the modalities of municipal solid waste management operations in the city. The service could be operated by the municipality itself or outsourced to formally organized micro and small scale enterprises for job creation and making wealth. If it is properly utilized, the efficiency of waste management could be in place. In Adama, the door to door collection service is outsourced to the formally organized micro and small scale enterprises in terms of implementing urban sanitation works. However, only $68 \%$ of the respondents have access to the door to door collection service. Hence, $32 \%$ of the respondents couldn't have the opportunity to get the service. in this case, people would try to find other options in order to get rid of their household waste, even it is inconvenient for them and not environmentally friendly such as burning in their compounds, disposing in any nearby open spaces, submitting to informal waste collectors Unfortunately, the informal waste collectors mostly dispose wastes at the cost of health and the environment for self-interest to create income for fortune. Besides, the respondents feel that about the effort made by the municipality to provide efficient solid waste management service compared with other services of the city such as water supply, electricity, telephone, etc. varies considerably. Hence, about $43 \%$ of the respondents in the study consider that it takes less effort to provide efficient solid waste management service for the municipality than if it was to provide other types of services such as water supply, electricity, telephone, etc. About $28 \%$ of them feel as it is fair for them. In general, the level of satisfaction of the respondents concerning solid waste management service and practice in the city varies considerably as shown in (Figure 9).

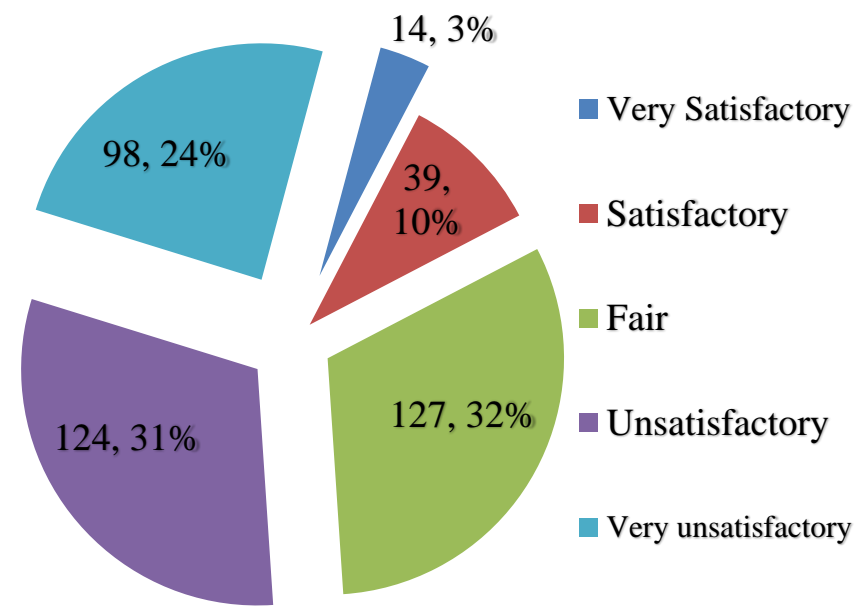

Figure 9: Satisfaction Level of Respondents on Solid Waste
Management Service of the Municipality.

The assessment result shows that about $31 \%$ of them feel unsatisfied, $32 \%$ of them feel fair, and $24 \%$ of them feel very unsatisfactory. Hence, the municipality has to do more on the solid waste management system in collaboration with all concerned parties to bring efficiency and satisfaction to its customers.

\section{Factors that Influence MSWM Services}

The solid waste management practice in Adama is very poor due to different internal and external factors. Some of the major gaps seen in solid waste management of the city are described as follows: firstly, Lack of promotion on waste reduction, there are weak enforcement and monitoring of MSEs to conduct their job properly. The coverage of their service is 
very limited, the quality of their services is very poor, there is not enough motivation for workers in microenterprises to operate the service, secondly, Lack of a properly designed collection route system and schedule, segregation at the source is very limited, waste recycling practice is very weak and composting practices by the waste pickers and by the community as well is very low. Thirdly, there is no proper waste transportation, disposal practices, adequate sanitation facilities to minimize the burden of transporting material for small enterprises, Waste pickers use horse-driven and hand-driven carts for the collection and transportation of wastes. Wastes are carried by sacks. There are no adequate waste collection containers and temporary waste collection sites.

There is no standardized solid waste transfer station, even after recycling and composting wastes, a great portion of them is still left behind. The municipality has no proper solid waste collection and transportation facilities. Instead, there is one tractor used for transporting wastes collected from streets, ditches, and roadsides to the final disposal site. A loader is used to load the wastes and open back trucks are used for transporting wastes to the disposal site. Poor infrastructure provision makes most of the city inaccessible, the first and the most important missing element in this service is the absence of a standardized final waste disposal site due to lack of leaders' attention. Hence, an open disposal site is used for handling municipal wastes, Poor landfill/dumpsite management, Lack of manpower and technical skill remains to be the most important bottleneck in addressing waste collection and landfill management.

\section{Current solid waste management system flow chart analysis in Adama City}

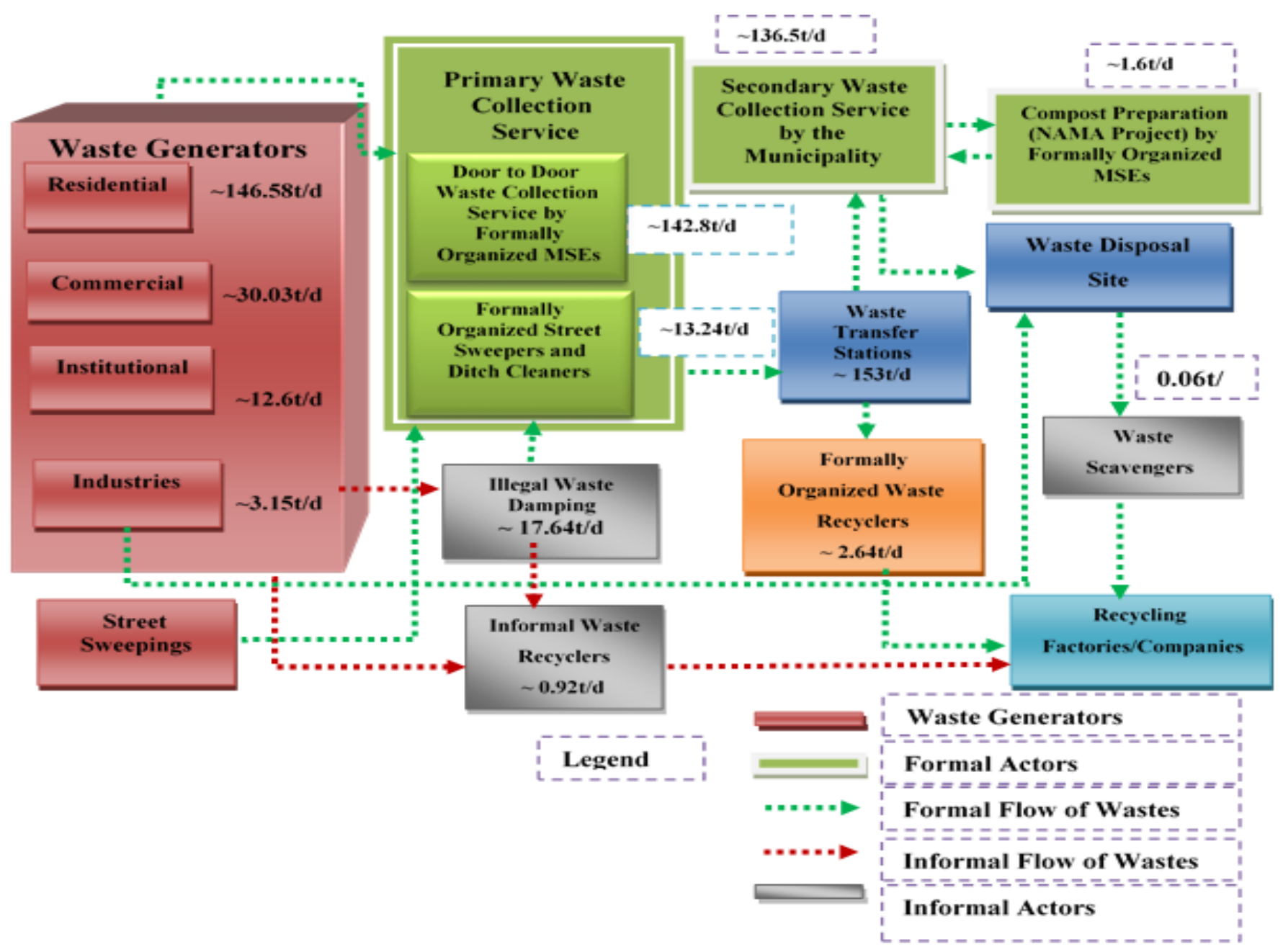

Figure 10: Current Solid Waste Management System Flow Chart in Adama City.

Source: survey result, 2020 
As shown in (Figure 10) above, the amount of waste generation in Adama City is estimated to be more than 210 tons per day (t/d) of which $146.58 \mathrm{t} / \mathrm{d}, 30.03 \mathrm{t} / \mathrm{d}, 12.6 \mathrm{t} / \mathrm{d}, 3.15 \mathrm{t} / \mathrm{d}$, and 17.64 $\mathrm{t} / \mathrm{d}$ are generated from residential, commercial, institutional, industrial and street sweepings respectively. About $142.8 \mathrm{t} / \mathrm{d}$ wastes could be collected by door to door collection service providers from waste generators with service fee and $13.24 \mathrm{t} / \mathrm{d}$ wastes could be collected from streets ditches and transported to waste transfer stations. Then, the secondary waste collection service is conducted by the municipality. About $139.65 \mathrm{t} / \mathrm{d}$ wastes can be disposed to the final disposal site of about 136.5 $\mathrm{t} / \mathrm{d}$ wastes are handled by the municipality and about $3.15 \mathrm{t} / \mathrm{d}$ could be transported to the disposal site by the industry owners or their delegates. In the meantime, around $1.6 \mathrm{t} / \mathrm{d}$ of decomposable wastes go to compost preparation site and 3.62 $\mathrm{t} / \mathrm{d}$ of recyclable wastes are collected by formal $(2.64 \mathrm{t} / \mathrm{d})$ and informal $(0.98 \mathrm{t} / \mathrm{d})$ waste recyclers. Periodically, these recyclable wastes are sold to waste recycling factories.

\section{The Environmental Problems Associated with the IMSWM}

The major environmental challenges that have been emerged due to improper management of wastes are water and drainage systems are blocked by wastes, humans and wild animals are threatened severely, the natural beauty of the environment is lost and hence it affects tourist attraction, occupational health of waste management workers and waste pickers are not safe, insects and other vermin are breeding and hence the opportunity of vermin borne diseases spreading is high.

\section{CONCLUSIONS AND RECOMMENDATIONS}

As displayed in the study, the majority of households are not satisfied with the current SWM services provided by the municipality. Human resources required by SWM at the subcity and kebele level are very limited, with a gap up to $50 \%$. Moreover, the waste management coverage and facilities are inadequate. There is inefficiency in waste collection, transportation, treatment, recycling and reuse, and disposal of wastes. The average waste generation in the city is 0.42 $\mathrm{kg} /$ day/capita which is beyond the national average level of $0.33 \mathrm{~kg} /$ day $/$ capita. In total, about 69,536 metric tons of wastes are generated annually. To treat the waste in a sustainable way, the following recommendations are proposed: (i) promoting and enforcing waste sorting at source; (ii) increasing solid waste collection and transfer stations, and strengthening street sweeping works; (iii) developing waste recycling, composting, and disposal facilities; and (iv) Enhancing environmental awareness and participation of stakeholders.

\section{ACKNOWLEDGEMENTS}

First, I would like to thanks the almighty GOD who helped me in all matters. Second, my advisor Professor ZHAO Jianfu, and Professor WANG Tao for his unreserved and invaluable comments. The research was supported by the National Natural Science Foundation of China (Grant No. 71974144). Third, my appreciation to MOFCOM and the China
Government, UNEP-Tongji Institute of Environment for Sustainable Development (IESD), Tongji University, the Government of Ethiopia and Oromia Regional State, Adama City Municipality, leaders as well as household respondents, Fourth, I would like to thanks my wife Melesu Deressa for giving me moral motivation for my study, Lastly, but not least, my younger brother Mr. Gizachew Mijena for coordinating all available data collection activities with my Son Wakbeka Alemayehu and my nephew Japan Amsalu; my appreciation and thanks be for all of them.

\section{References}

[1] S. Kaza, L. Yao, P. Bhada-Tata, and F. Van Woerden, What a waste 2.0: a global snapshot of solid waste management to 2050. The World Bank, 2018.

[2] L. C. Malav et al., "A review on municipal solid waste as a renewable source for waste-to-energy project in India: current practices, challenges, and future opportunities," Journal of Cleaner Production, vol. 277, p. 123227, 2020.

[3] F. ABUYE, T. JEGORA, and F. GAMACHU, "ASSESSMENT OF SOLID WASTE MANAGEMENT PRACTICES IN BEDELE TOWN, OROMIA, ETHIOPIA," Ethiopian Journal of Environmental Studies \& Management, vol. 12, no. 5, 2019.

[4] H. Desta, H. Worku, and A. Fetene, "Assessment of the contemporary municipal solid waste management in urban environment: The case of Addis Ababa, Ethiopia," J Environ Sci Technol, vol. 7, pp. 107-122, 2014.

[5] D. Hoornweg and P. Bhada-Tata, "What a waste: a global review of solid waste management," 2012.

[6] M. Oteng-Ababio, "E-waste: an emerging challenge to solid waste management in Ghana," International Development Planning Review, vol. 32, no. 2, pp. 191-206, 2010.

[7] G. W. Dickerson, Description and use of municipal solid waste composts in New Mexico. Cooperative Extension Service, College of Agriculture and Home Economics ..., 1999.

[8] S. Rathi, "Optimization model for integrated municipal solid waste management in Mumbai, India," Environment and development economics, vol. 12, no. 1, pp. 105-121, 2007.

[9] G. ZEMENA, "SOLID WASTE MANAGEMENT PRACTICE AND FACTORS INFLUENCING ITS EFFECTIVENESS. THE CASE OF SELECTED PRIVATE WASTE COLLECTING COMPANIES IN ADDIS ABABA," St. Mary's University, 2016.

[10] J. Pichtel, Waste management practices: municipal, hazardous, and industrial. CRC press, 2005.

[11] A. Walz et al., "Participatory scenario analysis for integrated regional modelling," Landscape and Urban Planning, vol. 81, no. 1-2, pp. 114-131, 2007

[12] A. V. Shekdar, "Sustainable solid waste management: an integrated approach for Asian countries," Waste management, vol. 29, no. 4, pp. 1438-1448, 2009.

[13] I. A. Al-Khatib, M. Monou, A. S. F. A. Zahra, H. Q. Shaheen, and D. Kassinos, "Solid waste characterization, quantification and management practices in developing countries. A case study: Nablus district-Palestine," Journal of environmental management, vol. 91, no. 5, pp. 1131-1138, 2010.

[14] M. Hailemariam and A. Ajeme, "Solid waste management in Adama, Ethiopia: Aspects and challenges," International Journal of Environmental, Chemical, Ecological, Geological and Geophysical Engineering, vol. 8, no. 9, pp. 670-676, 2014.

[15] A. A. Woldetsadik, "Practices of Solid Waste Management by Municipality and Community in Oromia Regional State of Ethiopia: a Case of Adama City, Ethiopia."

[16] S. F. Hayleeyesus and W. Cherinete, "Healthcare waste generation and management in public healthcare facilities in Adama, Ethiopia," Journal of Health and Pollution, vol. 6, no. 10, pp. 64-73, 2016.

[17] A. Pires, G. Martinho, and N.-B. Chang, "Solid waste management in European countries: A review of systems analysis techniques," 
Journal of environmental management, vol. 92, no. 4, pp. 10331050, 2011.

[18] M. Hailemariam and A. Ajeme, "Solid waste management in Adama, Ethiopia: Aspects and challenges," International Journal of Environmental, Ecological, Geological and Geophysical Engineering, World Academy of Science, Engineering and Technology, vol. 8, no. 9, 2014.

[19] T. File, H. Dinka, and L. Golassa, "A retrospective analysis on the transmission of Plasmodium falciparum and Plasmodium vivax: the case of Adama City, East Shoa Zone, Oromia, Ethiopia," Malaria Journal, vol. 18, no. 1, p. 193, 2019/06/11 2019.

[20] T. Yamane, "Statistics: An introductory analysis," 1967.

[21] T. Yamane, Problems to accompany" Statistics, an introductory analysis". Harper \& Row, 1967.

[22] I. Writers, "How to calculate a reliable sample size using Taro Yamane method," ed, 2016.

\section{ACRONYMS}

MSW: Municipal Solid Waste

SWM: Solid Waste management

IMSW: Integrated Municipal Solid Waste

IMSWM: Integrated Municipal Solid Waste Management

ISWM: Integrated Sustainable Waste Management

SWMS: Solid Waste Management System

Kg/HH/D: Kilogram per household per day

Kg/Cap/D: Kilogram per capita per day

KM: Kilo Meter

m: Meter

MSEs: Micro and Small Scale Enterprises

NAMA: Nationally Appropriate Mitigation Action
[23] T. Yamane, Statistics: An introduction analysis. Harper \& Row, 1973.

[24] H. Ak and W. Braida, "Sustainable municipal solid waste management decision making," Management of Environmental Quality: An International Journal, 2015.

[25] D. Tadesse, "Financial Urban Infrastructure and Services in Ethiopia: The Case of Solid Waste Management in Adama Town," ed: Ethiopia, 2001.

[26] F. MoUDC, "Urban Development Policy," Addis Ababa, 2012.

[27] A. Lemma, "Household Solid Waste Generation Rate and Composition: Analysis in two Selected Kebeles of Adama Town," M. Sc. Thesis, School of Graduate Studies of Addis, Ababa University, Addis ..., 2007.

[28] M. T. Awulachew, "Energy Recovery from Solid Waste for Nazareth/Adama City, Ethiopia," International Journal of Energy and Environmental Science, vol. 4, no. 3, p. 35, 2019.

\section{AUTHORS}

First Author - Kitila Alemayehu Mijena, Master candidate, Tongji University, UNEP-Tongji Institute of Environment for Sustainable Development (IESD) and College of Environmental science and Engineering; Email: alexmijena@gmail.com; Tel.: +86 19821813310; Address: 1239 Siping Road, Shanghai 200092, China.

Second Author -Jianfu Zhao, Mentor and supervisor, Tongji University, UNEP-Tongji Institute of Environment for Sustainable Development (IESD) and College of Environmental science and Engineering; Email: zhaojianfu@tongji.edu.cn; Tel.: +86 (21) 55054913; Address: 1239 Siping Road, Shanghai 200092, China.

Third Author - Sha Lu, Researcher, Tongji University, Circular Economy Research Institute, Marxism Faculty; Email: lusha_666@hotmail.com; Tel.: +86 18516608033; Address: 1239 Siping Road, Shanghai 200092, China.

Fourth Author-Tao Wang, Mentor and supervisor, Tongji University, UNEP-Tongji Institute of Environment for Sustainable Development(IESD); Email: a.t.wang@foxmail.com; Tel: +86 21 55088683; Address: 1239 Siping Road, Shanghai 200092, China.

Fifth Author - Kitila Gizachew Mijena, Government of Ethiopia and Oromia Regional State Government of Ethiopia and Oromia Regional State, Bureau of Labor and Social Affairs, Employment Study Expert Email: gizachewmijena@gmail.com; Tel.: +251912182475; Address: Addis Ababa, Ethiopia.

Correspondence Author - Tao Wang, email address: a.t.wang@foxmail.com; Tel: +86 21 55088683; Address: 1239 Siping Road, Shanghai 200092, China. 